\title{
PENGUJIAN SALMONELLA DENGAN MENGGUNAKAN MEDIA SSA DAN $E$. coli MENGGUNAKAN MEDIA EMBA PADA BAHAN PANGAN
}

\author{
Awalul Fatiqin ${ }^{1 *}$, Riri Novita ${ }^{2}$, Ike Apriani ${ }^{3}$ \\ ${ }^{123}$ Prodi Biologi, Fakultas Sains dan Teknologi, \\ Universitas Islam Negeri Raden Fatah Palembang \\ *e-mail:awalulfatiqin_uin@radenfatah.ac.id
}

\begin{abstract}
ABSTRAK
Umumnya bahan pangan berupa ikan dan daging olahan merupakan bahan pangan yang mudah rusak (perishable food) karena kandungan protein dan air yang cukup tinggi, oleh karena itu perlakuan dan pengolahan yang baik sangat diperlukan untuk bahan pangan tersebut. Adapun tujuan dari penelitian ini adalah untuk mendeteksi bakteri Salmonella sp dengan media SSA (Salmonella shigela agar) dan E-coli dengan media EMBA (Eosin Methylene Blue Agar) pada beberapa bahan pangan yang berasal dari ikan dan daging olahan. Sampel yang diuji berupa daging ikan giling, ikan asin, makanan kaleng dan sosis. Metode yang digunakan adalah uji pendugaan dengan menggunakan media selektif SSA dan EMBA dengan teknik media tuang. Hasil penelitian ini menunjukkan bahwa semua bahan pangan yang diuji untuk mendeteksi adanya Salmonella Sp. dengan menggunakan media SSA menunjukkan hasil yang negatif. Untuk uji deteksi adanya $E$ coli dengan menggunakan media EMBA pada bahan pangan yang diuji menunjukkan sampel daging ikan giling positif mengandung bakteri E-coli.
\end{abstract}

Kata kunci: Deteksi bakteri salmonella dan E-coli, EMBA, SSA

\begin{abstract}
Generally Food Ingredients Form of fish and processed meat is a perishable food material because protein content and the water is high enough, therefore treatment and processing of good it is necessary to review the food ingredients. The purpose from research is to review detecting bacteria Salmonella sp. with SSA (Salmonella Shigela Agar) and E-coli with EMBA (Eosin Methylene Blue Agar) on several of food derived from fish and processed meat. The samples were tested form of minced fish meat, salted fish, canned foods and sausage. The method used is testing with estimation using SSA and EMBA with pour plate technique. Research shows that the initials all food ingredients the tested to detect the presence of Salmonella Sp. review with using SSA findings indicate a negative thing. To test the presence of E-coli detection uses EMBA with the food ingredients the samples tested showed positive minced fish meat contains bacteria $E$-coli.
\end{abstract}

Keywords: Detection of bacteria salmonella and E-coli, EMBA, SSA 


\section{PENDAHULUAN}

Menurut UU RI No.7 tahun 1996, yang dimaksud pangan adalah segala sesuatu yang berasal dari sumber hayati dan air, baik yang diolah maupun tidak diolah, yang diperuntukkan sebagai makanan atau minuman bagi konsumsi manusia termasuk bahan tambahan pangan, bahan baku pangan, dan bahan lain yang digunakan dalam proses penyiapan, pengolahan dan atau pembuatan makanan atau minuman. Mengingat definisi pangan mempunyai cakupan yang luas, maka upaya untuk mencegah pangan dari kemungkinan tercemar baik dari cemaran biologis, kimia, dan benda lain yang yang dapat mengganggu, merugikan dan membahayakan kesehatan manusia (BPOM, 2008).

Bahan pangan dapat bertindak sebagai perantara atau substrat untuk pertumbuhan mikroorganisme patogenik dan organisme lain penyebab penyakit. Penyakit menular yang cukup berbahaya seperti tifus, kolera, disentri, atau TBC mudah tersebar melalui bahan makanan. Hampir semua bahan pangan tercemar oleh berbagai mikroorganisme dari lingkungan sekitarnya. Beberapa jenis mikroba yang terdapat pada bahan pangan adalah Salmonella sp., Staphylococcus aureus, Escherichia coli, kapang, khamir serta mikroba patogen lainnya. Mikroba mempunyai batasan tertentu dalam bahan pangan yang berpengaruh terhadap ketahanan bahan pangan. Kondisi lingkungan juga mempengaruhi mikroba untuk tumbuh dan berkembang lebih cepat (Hartoko, 2007).

Selain harus bergizi dan menarik, pangan juga harus bebas dari bahan-bahan berbahaya yang dapat berupa cemaran kimia, mikroba dan bahan lainnya. Pangan dapat menjadi beracun karena telah terkontaminasi oleh bakteri patogen yang kemudian dapat tumbuh dan berkembang biak selama penyimpanan, sehingga mampu memproduksi toksin yang dapat membahayakan manusia (BPOM, 2008). Meurut (Anonymous, 2010), Ikan segar, ikan awetan dan olahan produknya merupakan komuditi bahan pangan yang digunakan oleh masyarakat, hal ini dikarenakan nilai gizi tinggi, kaya akan protein, lemak, mineral serta zat lainnya yang sangat dibutuhkan tubuh. Bahan pangan tersebut dapat tercemar oleh berbagai mikroorganisme dari lingkungan sekitar seperti mikroba Escherichia coli dan Salmonella sp.

Proses pengolahan dan pengawetan makanan tidak sepenuhnya dapat mencegah semua perubahan-perubahan yang merugikan, seperti pada makanan yang telah diawetkan dengan pembekuan atau pengeringan. Enzim-enzim hasil metabolit bakteri yang terdapat di dalam bahan pangan masih mungkin aktif dan menyebabkan perubahan warna, tekstur, maupun cita rasa dari suatu produk pangan. Pengujian mutu suatu bahan pangan diperlukan berbagai uji yang mencakup uji fisik, uji kimia, uji mikrobiologi, dan uji organoleptik. Uji mikrobiologi merupakan salah satu uji yang penting, karena selain dapat menduga daya tahan dalam penyimpanan suatu makanan juga dapat digunakan sebagai indikator sanitasi makanan atau indikator keamanan makanan. Pengujian mikrobiologi di antaranya meliputi uji kualitatif untuk menetukan mutu dan daya tahan suatu makanan, uji kuantitatif bakteri patogen untuk menentukan tingkat keamanannya, dan uji bakteri indikator untuk mengetahui tingkat sanitasi makanan tersebut (Fardiaz, 1993).

Mikrobiologi pangan adalah ilmu yang mempelajari tentang pengaruh sel mikroorganisme pada proses pengolahan bahan pangan, termasuk mekanisme ketahanan mikroorganisme terhadap proses pengolahannya. Ilmu mikrobiologi pangan selain itu juga merupakan ilmu yang 
mempelajari tentang perubahan-perubahan yang merugikan seperti kebusukan dan keracunan makanan maupun perubahanperubahan yang menguntungkan seperti dalam fermentasi makanan (Volk 1988). Bahan pangan dapat mengandung mikroba ataupun vektor yang mampu memindahkan sebaran penyakit. Bahan pangan yang mengandung nutrien organik merupakan media yang menunjang pertumbuhan dan reproduksi mikroba yang berlangsung pada suhu lingkungan tertentu. Bahan pangan dapat terkontaminasi oleh berbagai sumber seperti tanah, air, peralatan, mikroba saluran pencernaan manusia, mikroba saluran pencernaan hewan, pekerja yang menangani bahan pangan, hewan, dan pakan (Sunatmo 2009).

Pertumbuhan mikroba pada pangan dapat menimbulkan berbagai perubahan, baik yang merugikan maupun yang menguntungkan. Mikroba yang menguntungkan berperan dalam prosesproses perombakan dan penyusunan senyawa organik (makanan) sehingga menghasilkan berbagai produk yang bermanfaat bagi manusia, misalnya dalam pembuatan tempe, oncom, kecap, tauco, tape dan lain-lain. Mikroba yang merugikan berperan sebagai agen pengkontaminasi dan pembusukan pada makanan sehingga menyebabkan kerugian pada produksi pangan (Abi, 2010).

Escherichia coli merupakan bakteri Gram negatif berbentuk batang pendek yang memiliki panjang sekitar $2 \mu \mathrm{m}$, diameter $0,7 \mu \mathrm{m}$, lebar $0,4-0,7 \mu \mathrm{m}$ dan bersifat anaerob fakultatif. Escherichia coli membentuk koloni yang bundar, cembung, dan halus dengan tepi yang nyata (Kusuma, 2010).

Bakteri Escherichia coli termasuk bakteri yang berbentuk batang, Gram negatif, fakultatif anaerob, dan tak mampu membentuk spora (Hendri dan Prasetyowati, 2006). Klasifikasi bakteri Escherichia coli menurut Jawest at al (2010), adalah sebagai berikut: Kingdom Prokaryotae, Phyllum Proteobacteria, Class
Zymobacteria, Order Enterobacteriales, Family Enterobacteriaceae, Genus Escherichia, Spesies Escherichia coli.

Escherichia coli merupakan bakteri indikator kualitas air minum karena keberadaannya di dalam air mengindikasikan bahwa air tersebut terkontaminasi oleh feses, yang kemungkinan juga mengandung mikroorganisme enterik patogen lainnya (Anggraini $d k k$, 2013).

Escherichia coli menjadi patogen jika jumlah bakteri ini dalam saluran pencernaan meningkat atau berada di luar usus. Escherichia coli menghasilkan enterotoksin yang menyebabkan beberapa kasus diare. Escherichia coli berasosiasi dengan enteropatogenik menghasilkan enterotoksin pada sel epitel (jawetz et al., 1995 dalam Kusuma, 2010).

Salmonella adalah bakteri pendek (1$2 \mu \mathrm{m})$, Gram negatif, batang yang tidak membentuk spora, biasanya motil dengan flagella peritrisous. Salmonella adalah anaerob fakultatif yang secara biokimia dikarakterisasi dengan kemampuannya memfermentasi glukosa yang memproduksi asam dan gas, dan ketidakmampuannya menggunakan laktosa dan sukrosa. Temperatur pertumbuhan optimumnya $38^{\circ} \mathrm{C}$. Salmonella dapat tumbuh pada aktivitas air yang rendah $(\mathrm{aw} \leq 0,93)$ yang responnya tergantung strain dan jenis pangan. Salmonella aktif bertumbuh pada kisaran $\mathrm{pH}$ 3,6 - 9,5 dan optimal pada nilai pH mendekati normal (Isyana, 2012).

Infeksi oleh bakteri Salmonella sp. (oleh sebab itu disebut Salmonellosis) menyerang saluran gastrointestin yang mencangkup perut, usus halus, dan usus besar atau kolon. Beberapa spesies Salmonella sp. dapat menyebabkan infeksi makanan. Termasuk kedalamnya ialah Salmonella enteritidis var typhimurium dan varietas-vairetas lain serta Salmonella choleraesuis. Bakteri ini ialah batang Gram negatif, motil, tidak membentuk spora, dapat memfermentasi glukosa, tetapi tidak memfermentasi laktosa atau sukrosa. 
Hampir semua serotipe membentuk gas bila memfermentasi gula, kecuali Salmonella typhi (Irianto, 2006).

Menurut reaksi biokimiawinya, Salmonella dapat diklasifikasikan menjadi tiga spesies, yaitu: Salmonella typhi, Salmonella choleraesuis, dan Salmonella enteritidis. Terinfeksinya manusia oleh Salmonella hampir selalu disebabkan mengkonsumsi makanan atau minuman tercemar. Meskipun demikian, sumber Salmonellosis terbesar yang merupakan gudang Salmonella ialah hewan tingkat rendah (Irianto, 2006).

Media adalah seam substami yang komposisinya terdin dan nutrisi tertentu yang diperlukan untuk menumbuhkan den mempelajari sifat-sifat bakten. Komposisi nutrisi media yang komplit mengandung somber karbon, nitrogen, belerang, fosfat, logam mikro, vitamin, penyubur, $\mathrm{NaCl}$ dan air (Sutarma, 2000).

Ditinjau dari sudut keperluan/penggunaan dan sifat-sifatnya dari lebih 90 macam media yang telah dibuat dapat digolongkan menjadi 6 klasifikasi berdasarkan sumber nutrisinya, bentuk fisik komposisi kimia, perbedaan pertumbuhan bakterinya, dapat tidaknya menyeleksi/menghambat bakteri yang tak diinginkan (Sutarma, 2000).

Media SSA merupakan media yang mempunyai selektif tinggi untuk isolasi Salmonella sp.. Salmomella shigella agar adalah media selektif untuk mengisolasi kuman Salmonella sp. dan Shigella sp. dari sampel feses, urin, dan makanan (Hada, 2011). Media Eosin Methylen Blue Agar (EMBA) merupakan media diferensial untuk Escherichia coli. Media diferensial merupakan media yang dapat menumbuhkan beberapa jenis bakteri dan menyebabkan koloni-koloni suatu bakteri tertentu mendapatkan bentuk yang khas. Media ini menumbuhkan bakteri kelompok Enterobacteriaceae, salah satunya adalah Escherichia coli yang akan tumbuh dengan membentuk koloni berwarna spesifik dengan ciri-ciri bentuk bulat, diameter 2-3 mm, warna hijau dengan kilap logam dan bintik biru kehijauan di tengahnya (Kusuma, 2010).

Penghitungan jumlah bakteri coli umumnya dilakukan dengan menggunakan tabel Hopkins yang lebih dikenal dengan nama MPN (most probable number) atau tabel JPT (jumlah perkiraan terdekat), tabel tersebut dapat digunakan untuk memperkirakan jumlah bakteri coli dalam $100 \mathrm{ml}$ dan $0,1 \mathrm{ml}$ contoh air (Manurung, 2012).

Dalam kegiatan mikrobiologi pembuatan isolat dilakukan dengan cara mengambil sampel mikrobiologi dari lingkungan yang ingin diteliti. Dari sampel tersebut kemudian dibiakkan dengan menggunakan media universal atau media selektif, tergantung tujuan yang ingin dicapai. Jika menggunakan media universal akan diperoleh biakan mikroba campuran. Untuk proses identifikasi maupun isolasi jenis tertentu saja, dilakukan proses pembuatan isolat tunggal dari isolat campuran tersebut. Isolat tunggal atau biakan murni merupakan biakan yang asalnya dari pembelahan satu sel tunggal (Manurung, 2012).

Ada beberapa metode untuk memperoleh biakan murni dari isolat campuran. Dua di antaranya yang sering digunakan adalah teknik cawan gores dan teknik cawan tuang. Prinsip dari kedua teknik tersebut sama, yaitu mengencerkan biakan campuran hingga setiap individu spesies dapat dipisahkan, sehingga setiap koloni yang terbentuk merupakan hasil dari pembelahan satu sel (Manurung, 2012).

Cara penggarisan dilakukan pada medium pembiakan padat bentuk lempeng. Bila dilakukan dengan baik cara ini adalah yang paling praktis. Setiap laboratorium memiliki cara atau metode pengerjaan yang berbeda-beda, tetapi tujuannya adalah sama, yaitu untuk membuat garis sebanyak mungkin pada permukaan lempeng medium pembiakan dengan ose atau jarum bahan pemeriksaan yang terlepas pada garis-garis tersebut semakin lama semakin sedikit, 
sehingga pada garis-garis terakhir kolonikoloni bakteri yang terbentuk akan terpisah agak jauh (Irianto, 2006).

Metode cawan tuang merupakan teknik lain yang dapat digunakan untuk mendapatkan koloni murni mikroorganisme. Kelemahan metode ini adalah membutuhkan waktu dan bahan yang lama dan banyak, akan tetapi tidak memerlukan keterampilan tinggi. Biakan campuran diencerkan dengan menggunakan medium agar yang telah dicairkan dan didinginkan. Pengenceran dilakukan dalam beberapa tahap hingga diperoleh koloni tunggal (Manurung, 2012).

Isolasi bakteri dengan cara tuang ini umumnya dilakukan untuk menentukan perkiraan jumlah bakteri hidup dalam cairan, misalnya air, susu, kemih atau biakan bulyon. Hasilnya dinyatakan dalam jumlah koloni, yang berarti jumlah bakteri hidup dalam tiap mililiter cairan yang diperiksa (Irianto, 2006).

\section{BAHAN DAN METODE}

Sampel berupa daging ikan giling segar, makanan kaleng, ikan awetan (asinan), sosis/cornet daging diambil dari pasar tradisional KM 5 Palembang.

\section{Pembuatan Media}

Media SSA sebanyak 35 gr dan EMBA sebanyak 37.5 gr, masing-masing dilarutkan dalam 1 liter aquades kemudian dididihkan dan disterilisasi menggunakan autoklaf selama 30 menit dengan suhu $121^{\circ}$ C, 1 atm.

\section{Uji deteksi Bakteri Patogen pada Bahan}

\section{Pangan}

a. Tempat dan tangan peneliti disterilkan dengan menyemprotkan alkohol.

b. Sebanyak $10 \mathrm{~g}$ sampel (yang telah dihaluskan) diletakkan diatas aluminium foil, lalu dicampurkan kedalam $90 \quad \mathrm{ml}$ aquades steril (pengenceran $10^{-1}$ ).

c. Dilakukan pengocokan kuat (vortex) beberapa detik untuk memastikan sampel telah larut secara homogen

d. Sebanyak $1 \mathrm{ml}$ larutan pada pengenceran $10^{-1}$ diambil lalu masukkan kedalam tabung reaksi yang berisi $9 \mathrm{ml}$ aquades steril yang baru (pengenceran $10^{-2}$ )

e. Diambil sebanyak $1 \mathrm{ml}$ dari larutan suspensi sampel pada pengenceran $10^{-}$ ${ }^{1}$,dan $10^{-2}$ dengan metode tuang (pour plate) pada media SSA dan EMBA

f. Selanjutnya diinkubasi pada suhu $35^{\circ} \mathrm{C}$ selama 24 jam

g. Dilakukan pengamatan terhadap koloni bakteri Escherichia coli dan Salmonella Sp. yang tumbuh pada media SSA dan EMBA

h. Koloni Escherichia sp. (+) berwarna hijau metalik dengan bintik hitam di bagian tengahnya

i. Koloni Salmonella sp. (+) berwarna transparan dengan bintik hitam dibagian tengahnya.

j. Karakteristik makroskopis koloni diamati

\section{HASIL DAN PEMBAHASAN \\ Hasil Pengamatan}

Uji deteksi bakteri patogen dilakukan pada 4 jenis bahan pangan, yaitu daging ikan giling, ikan asin, makanan kaleng/sarden dan sosis. Penelitian ini menggunakan 2 jenis media selektif, yaitu media SSA (Salmonella-Shigella Agar) untuk mendeteksi bakteri Salmonella sp., media kedua yaitu, EMBA (Eosin Methylene Blue Agar) untuk mendeteksi bakteri Escherichia coli. Dari hasil pengujian didapatkan data sebagai berikut: 
Tabel 1. Hasil uji bakteri patogen pada bahan pangan menggunakan media EMBA dan SSA

\begin{tabular}{llcc}
\hline No & Sampel & SSA (Salmonella-Shigella agar) & EMBA (Eosin Methylene Blue Agar) \\
\hline 1. & Ikan giling & - & + \\
2. & Ikan asin & - & - \\
3. & Makanan kaleng & - & - \\
4. & Sosis & - & - \\
\hline
\end{tabular}

Keterangan :

+ : Positif keberadaan bakteri patogen

- : Negatif keberadaan bakteri patogen

Pengamatan Makroskopis Bakteri Patogen pada Bahan Pangan

Dari ke-empat sampel bahan pangan yang diujikan pada 2 jenis media, didapatkan hasil positif pada sampel ikan giling yang ditumbuhkan pada media EMBA (Gambar $1)$.

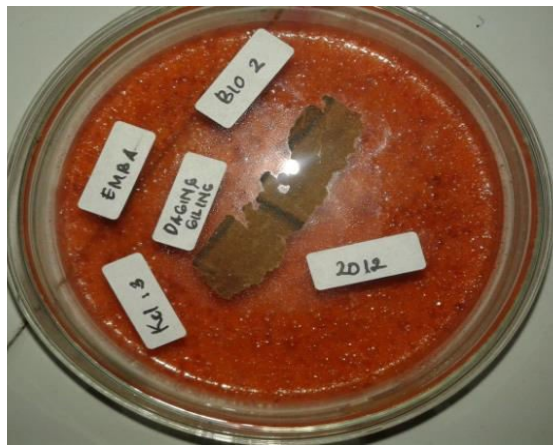

Gambar 1. Bakteri yang tumbuh pada media EMBA

\section{Pembahasan}

Hasil deteksi awal bakteri Escherichia sp. dan Salmonella Sp. pada sampel bahan pangan ditunjukkan pada Tabel 1. Pengujian keberadaan bakteri pada bahan pangan sangat penting dilakukan karena Indonesia telah mempunyai standar nasional yang berkaitan dengan keamanan pangan, yaitu Standar Nasional Indonesia (SNI). Standar ini diantaranya memuat tentang memproduksi bahan pangan yang benar, mengukur cemaran, dan menyajikan batas maksimum cemaran yang diperkenankan. Standar ini diharapkan dapat memberikan jaminan keamanan produk pangan Indonesia (Nasional, 1995). Salah satu pengujian mutu suatu bahan pangan yaitu uji mikrobiologi. Menurut Fardiaz (1993) uji mikrobiologi merupakan salah satu uji yang penting, karena selain dapat menduga daya tahan simpan suatu makanan, juga dapat digunakan sebagai indikator sanitasi makanan atau indikator keamanan makanan.

Uji deteksi bakteri Salmonella sp. pada daging ikan giling, ikan asin, makanan kaleng/sarden dan sosis menggunakan media selektif SSA (Salmonella-Shigella Agar) menunjukkan hasil negatif (Tabel 1). Menurut (Kartika, 2014), makanan yang tercemar oleh bakteri Salmonella sp. akan tumbuh pada media SSA, berbentuk bulat, elevasinya cembung dengan pinggiran rata, adanya perubahan warna media, yaitu kuning pada butt (dasar) dan merah pada slant (permukaan miring). Perubahan warna tersebut terjadi karena adanya fermentasi glukosa oleh Salmonella sp. Selain itu, keberadaan bakteri Salmonella sp. juga ditandai dengan pembentukan ruang udara di bawah medium sehingga medium akan terangkat ke atas. 
Hasil negatif untuk pengujian Salmonella sp. pada semua sampel bahan pangan (Tabel 1) menunjukkan bahwa sampel tersebut aman dari bakteri Salmonella sp. Respon negatif menunjukkan bahwa keempat bahan pangan ini tidak terkontaminasi bakteri Salmonella sp. Menurut (Nasional, 1995), Salmonella sp. merupakan indikator baik buruk atau aman tidaknya komoditas pangan daging dan olahannya. Beberapa bakteri Salmonella seperti Salmonella typhii, S.paratyphii A, dan S.paratyphi B digolongkan ke dalam mikroba patogen yang sangat berbahaya. Berdasarkan (Nasional, 1995)batasan maksimum cemaran mikroba untuk Salmonella sp. dalam bahan makanan asal hewan adalah negatif/25gram.

Hasil deteksi bakteri Escherichia sp. pada daging ikan giling menujukkan hasil yang positif. Ini ditunjukkan dengan adanya koloni berwarna hijau metalik mengkilat dengan titik hitam dibagian tengah koloni yang tumbuh pada media Eosin Methylene Blue Agar (EMBA). Hal ini sesuai dengan pernyataan (Suardana, 2014) dan Kusuma (2010), jika pada suatu pangan terkontaminasi bakteri $E$. coli maka hasil penumbuhan pada EMBA memperlihatkan koloni berwarna hijau metalik, diameter 2-3 $\mathrm{mm}$ dengan titik hitam di bagian tengah koloni. Pertumbuhan dicawan menunjukkan bakteri E. coli, tidak dihambat oleh eosin dan methylen biru, E. coli merupakan bakteri gram negatif. Warna hijau metalik mengkilat menunjukkan $E$. coli dapat memfermentasi laktosa menghasilkan produk akhir bersifat asam kuat. Menurut Arlita (2008), Escherchia coli merupakan bakteri gram negatif yang memfermentasikan laktosa yang berada dalam suhu kamar $37-38^{\circ} \mathrm{C}$ dalam waktu 24-48 jam.

Escherichia coli dapat tumbuh dengan cepat pada suhu $30-42^{\circ} \mathrm{C}$, tumbuh lambat pada suhu $44-45^{\circ} \mathrm{C}$, dan tidak dapat tumbuh pada suhu $10^{\circ} \mathrm{C}$ atau lebih rendah.
Strain ini resisten terhadap $\mathrm{pH} 4,5$ atau lebih rendah. Bakteri akan mati pada suhu pasteurisasi $64,3^{\circ} \mathrm{C}$ selama 9,6 detik, tetapi sel dapat bertahan hidup pada pangan dengan suhu $-20^{\circ} \mathrm{C}$ (Sopandi dan Wardah, 2014). Escherchia coli, atau biasa disingkat E.coli, adalah salah satu jenis spesies utama bakteri gram negatif. E-coli merupakan indikator dari kontaminan dengan sumber/ bahan fekal. Habitat alami dari E-coli adalah saluran pencernaan bawah hewan dan manusia (Arlita, 2008).

Berdasarkan Standar Nasional Indonesia (SNI) SNI 01-2719-1992 batasan maksimum cemaran total mikroba pada ikan segar adalah $5 \times 10^{5} \mathrm{cfu} /$ gram atau sebesar 5.70 log cfu/gram (Chio, 1981). Batas maksimum cemaran mikroba dalam bahan makanan asal hewan sesuai Standar Nasional Indonesia diantaranya adalah angka lempeng total (ALT) $1 \times 10^{4} \mathrm{cfu} / \mathrm{g}$, Escherichia coli 1 x $10^{1} \mathrm{cfu} / \mathrm{g}$ (Dewan Standarisasi Nasional, 1995).

Adanya kontaminasi bakteri Escherichia sp. pada daging ikan giling kemungkinan disebabkan oleh beberapa faktor. Menurut (Nasran, 1972), ada tiga faktor yang menyebabkan turunnya mutu ikan segar, yaitu cara penangkapan, faktor biologis, dan cara penanganan. Upaya yang dilakukan oleh setiap pasar modern untuk menjaga mutu ikan segar, hanya terbatas pada satu faktor saja yaitu cara penanganan dan hanya selama penjajakan saja. Selain itu, faktor lain adalah es batu yang digunakan sebagai alas ikan. Es batu yang digunakan menjadi faktor penyebab kontaminasi silang terhadap ikan. Ikan yang telah lama atau rusak akan meninggalkan cemaran bakteri pada alas es batu yang digunakan kembali sebagai alas ikan segar berikutnya.

Berdasarkan penelitian yang dilakukan oleh (Hartini, 2005), terhadap lima sampel es batu, diperoleh bahwa total mikroba yang terdapat pada es batu berkisar antara $6.1 \times 102$ sampai $9.8 \times 103$ $\mathrm{cfu} / \mathrm{ml}$, selain itu analisis yang lebih spesifik lagi terhadap spesies bakteri yang 
terdapat pada es batu menggunakan perangkat API 20E antara lain diperoleh E.coli $(10 \%)$, Enterobacter sp (10\%), Enterobacter cloacae (20\%), Pseudomonas sp (10\%), Citrobacter (10 \%), dan Klebsiella (20\%), hasil penelitian ini menjadi dasar terhadap adanya dugaan kontaminasi yang berasal dari es batu terhadap ikan yang dijual.

Dua faktor lain yaitu (cara penangkapan dan faktor biologis) inilah yang diduga menjadi penyebab rendahnya mutu ikan sebelum ikan sampai ke tangan penjual. Sementara itu, untuk pasar tradisional rendahnya mutu ikan diduga akibat dari buruknya penanganan dan cara penangkapan serta faktor biologis yang berasal dari ikan itu sendiri (Nasran, 1972).

\section{KESIMPULAN}

Dari hasil penelitian terhadap dekteksi dini bakteri Escherichia coli. dan Salmonella Sp. pada bahan pangan disimpulkan bahwa uji deteksi bakteri Salmonella sp. pada daging ikan giling, ikan asin, makanan kaleng/sarden dan sosis menggunakan media selektif SSA (Salmonella-Shigella Agar) menunjukkan hasil yang negatif. Untuk uji deteksi bakteri Escherichia coli pada bahan pangan berupa daging ikan giling menggunakan media selektif EMBA menunjukkan hasil yang positif. Kontaminasi E. coli pada daging ikan giling yang diambil dari pasar KM 5 Palembang kemungkinan disebabkan oleh cara penangkapan, faktor biologis, dan cara penanganan yang kurang baik.

\section{DAFTAR PUSTAKA}

Anonimus. (2010). Media Uji Pemecahan Komponen Makanan Oleh Mikroorganisme. Juni 2015: http://lordbroken.wodpress.com/2010 /07/27.html.

Arlita. (2018). Identifikasi Bakteri Escherichia coli dan Salmonella sp.
Pada Makanan Jajanan BaksoTusuk di Kota Manado. Universitas Samratulangi. Manado

BPOM. (2008). Pengujian Mikrobiologi Pangan. Jakarta: www2.pom.go.id/. pdf.

Fardiaz, S. (1993). Analisis Mikrobiologi Pangan. Jakarta: PT. Raja Grafindo Persada.

Hartini, U. S. (2005). Analisis Kandungan dan Kemampuan Bertahan Salmonella pada Es Batu dalam Rangka Evaluasi Keamanan Pangan. Skripsi Fakultas Teknologi Pertanian. Institut Pertanian Bogor. Bandung.

Kartika, E. (2014). Deteksi Bakteri Indikator Keamanan Pangan Pada Sosis Daging Ayam Di Pasar Flamboyan Pontianak. Pontianak: Universitas Pontianak.

Nasional, D. S. (1995). SNI 01-3924-1995 tentang Mutu Daging Pedaging. Departemen Pertanian. BSN. Jakarta.

Nasran, S. (1972). Handling Ikan Basah. Petunjuk Praktis Dalam Handling. Di dalam Lembaga Teknologi Perikanan (eds.). Ikan Basah: Mutu, Cara-cara Handling dan Sarana yang Diperlukan. LTP. Jakarta.

Suardana, I. U. (2014). Identification of Escherichia coli O157:H7 from Chicken Feces and Test of Hemolytic Profile on Blood Agar Medium. Jurnal Kedokteran Hewan, 8 (1). 